UDC 811.163.41’366.596

https://doi.org/10.18485/ms zmsfil.2021.64.2.6

Изворни научни рад

Гордана Штасни

Милан Ајџановић

\title{
СЕМАНТИЧКО-ДЕРИВАЦИОНИ ПОТЕНЦИЈАЛ ГЛАГОЛА ЛЕТЕТИ
}

\begin{abstract}
Глаголи кретања представљају једно од најважнијих семантичких глаголских поља, а међу њима глаголу лет̄ет̄u припада истакнуто место јер се њиме формализује вид кретања кроз ваздушни простор. Теоријски и методолошки приступ одабраном предмету изучавања заснива се на елементима компоненцијалне и концептуалне анализе. Циљ је да се идентификују активне компоненте значења које омогућавају ширење семантичке структуре датог глагола, а с тим у вези и опис трансформационих механизама којима су индуковане његове секундарне реализације. Циљ анализе јесте и да се утврде појмовни домени на основу значења деривата који су у склопу гнезда с мотивним

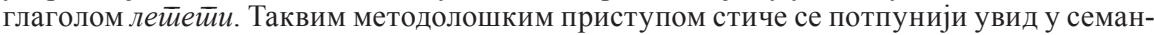
тичко-деривациони потенцијал посматраног глагола, али и способност померања категоријалне границе кретања према онима изван домена кретања - домен радње са другачијим семантичким обележјима, простора, животиње, човека, предмета, особина.

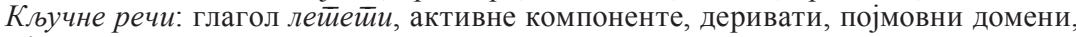
српски језик.
\end{abstract}

Verbs of motion represent one of the most important verbal semantic fields, among which the verb leteti 'fly' has a prominent place because it formalizes the type of motion through the air. The paper uses the elements of componential and conceptual analysis to identify the active components of meaning that enable the expansion of the semantic structure of the given verb, and in connection with that, the description of the transformation mechanisms that induces its secondary realizations. The aim of the analysis is to determine the conceptual domains based on the meaning of the derivatives that are members of the derivational nest formed around the verb leteti. Such a methodological approach provides a more complete insight into the semantic-derivational potential of the observed verb, but also the ability to broaden the categorical boundary of movement towards those outside the domain of movement - the domain of an action with different semantic features, space, animal, human, object, properties, etc.

Key words: verb leteti 'fly', active components, derivatives, conceptual domains, the Serbian language.

1. Увод. Један од начина да се у језику формализује концепт кретања, што је једно од главних обележја материје, живих бића и природе уопште, представљају глаголи, који су на основу тог семантичког маркера, свог заједничког обележја у рангу архисеме 'кретања', повезани у јединствену тематску групу. „Глаголи кретања, као и остали елементи који описују просторне односе, спадају у групу најчешће употребљаваних речи, имајући у виду да је „покрет”, као примарна физичка и визуелно-просторна појава, један од основних елемената у нашој концептуализацији света" (СтАменковић 2017: 18). ${ }^{1}$

${ }^{1}$ „Многи лингвисти (нпр. Strauss 1966, Young 1980, Lakoff 1987) сагласни су око тога да је кретање примарно људско искуство, а Максин Шитс-Џонстоун кроз феноменолошку анализу порекла, структуре и квалитета људског покрета доказује да покрет представља почетну тачку у процесу изградње значења (Sheets-Johnstone 1999: 3)" (Стаменковић 2017: 18). 
1.1. ПрЕДМЕТ истРАЖИВАњА. За предмет истраживања одабран је глагол лететей и његови деривати. Анализе су спроведене на јединицама ексцерпираним из РМС, којих, заједно с глаголом лет̄етии, има 121. ${ }^{2}$ Значења издвојених лексема такође су преузета из РМС.

Овом глаголу припада посебно место због чињенице да у лексичком систему не постоји одговарајући разнокоренски еквивалент, синонимна лексема, којом се концептуализује исти семантички садржај. ${ }^{3}$ Он је специфичан управо због своје денотативне функције, и издвојен из веома слојевите групе глагола кретања, о чијој семантичкој сложености сведоче бројни параметри који могу бити у основи њихове класификације. Наиме, на типолошки опис глагола кретања утиче читав низ чинилаца, какви су визуелна и просторна организација елемената кретања, врста покрета, брзина и правац кретања, удаљеност од тла, аблативност, адлативност, перлативност и др. Како се феномен кретања нужно доводи у везу с простором, у овом истраживању је класификација глагола кретања условљена одликама простора у којем се кретање одвија. Према Н. Ортену (1976), медијум кроз који се кретање реализује представља основни критеријум за њихову поделу, те се они деле на оне чија се радња одвија по земљи, кроз воду и у ваздуху. ${ }^{4}$ Чињеница је, такође, да и остали параметри који се сматрају релевантним за опис феномена кретања не могу бити занемарени, јер се поред доминантног критеријума простора у којем се радња означена глаголом летиейи одвија, у интерпретацију деривата који припадају овом гнезду нужно укључују и остали параметри којима се спецификује радња формализована у првом реду глаголским префиксалима (нпр. аблативност, перлативност, дифузност итд.).

1.2. ТЕОРИЈСКИ ПРИСТУП И цИљ РАДА. Како је главни циљ овога рада утврђивање семантичког и деривациог потенцијала глагола лет̄ей $и$, којим се

\footnotetext{
${ }^{2}$ У обзир се не узима некњижевни и периферни облик летиий и, који је забележен у РСАНУ, као ни деривати изведени од њега. Како наводи М. Спасојевић, колебања у вези с употребом

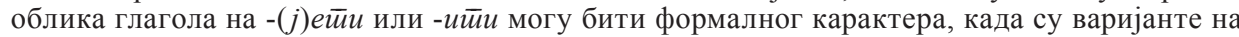

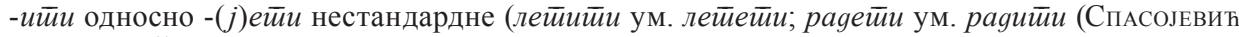
2013: 15-16)).

${ }^{3}$ Иако се поједине лексеме могу наћи у функцији контекстуалних синонима глагола летеией й ипак се оне не могу сматрати његовим одговарајућим семантичким еквивалентом - јеgритии у смислу летети, као што се морем једри помоћу једара, и ваздухом се једри: јеgри

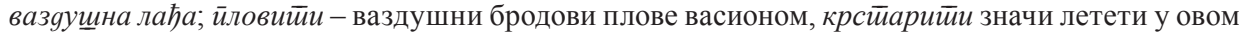
смислу: као орао који зраком лети сад на једну, сад на другу страну - орао крстиари небом,

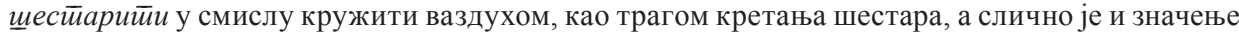

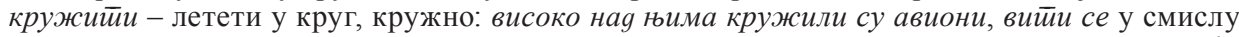
летети кретати се ваздухом наоколо изнад некога или нечега - не іризещи тии мени ущuи, веће

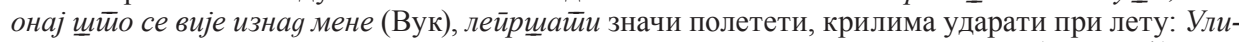

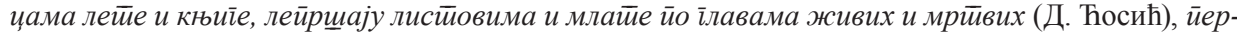
jā̄u у овом смислу значи кретати се перјем, дакле летети, али обично ниско, као поодрасли пилићи кад трче и помало полећу додирујући каткад земљу ногама, машући крилима живо се кретати (LALEVIĆ 2004: 332). Део овог синонимног низа могу, поред наведених, бити и лексеме у Речнику синонима у оквиру лексикографског чланка наведене под тачком 2: (о времену)

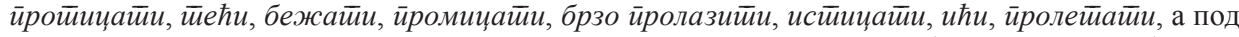

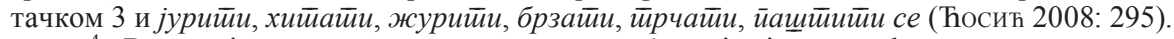

${ }^{4}$ „Ваздух је природно окружење човека без којег је немогуће живети и свако људско природно кретање одвија се кроз ваздух, али кретањем у ваздуху у овој класификацији сматра се оно кретање које се одвија без контакта са тлом”, објашњава Д. Вујовић (2019: 44).
} 
формализује кретање у ваздуху, за његово остваривање неопходно је спровести анализе семантичко-деривационог типа које се заснивају на елементима компоненцијалне и концептуалне анализе. Резултатима добијеним применом овако осмишљених аналитичких поступака могућа је провера једне од главних претпоставки у истраживању да секундарне реализације мотивне речи представљају индикаторе основних појмовних домена у које he се на основу својих примарних, али и секундарних реализација уклапати и деривати мотивисани глаголом лешемети.

1.2.1. Применом елемената компоненцијалне анализе утврђују се компоненте садржане у његовој појмовној вредности којима су индуковане секундарне реализације и трансформациони механизми посредством којих су таква значења настала. Компоненцијална анализа представља истовремено и теорију и метод који се користи у анализи и утврђивању семантичког садржаја и семантичке структуре речи. Семантички садржај речи обухвата компоненте значења које су хијерархијски устројене. Архисема је семантичка компонента највишег ранга и она доминира у организовању семантичког потенцијала речи и представља кључну тачку око које се одвија груписање речи на лексичке класе - лексичко-семантичке групе. Све остале семе називају се семе нижег ранга или диференцијалне семе (ГортАн-Премк 2004: 43). У науци је потврђена функционалност примене компоненцијалне анализе у семантичким истраживањима уопште (NIDA 1975), али и у испитивању глагола кретања (MiLLER 1972; NIDA 1975). ${ }^{5}$

1.2.2. У сагледавање глагола лет̄еӣu и његових деривата укључени су и елементи концептуалне анализе, с циљем да се утврде домени изван домена кретања у које се на основу свог значења уклапају идентификоване јединице и ентитети њима означени. ${ }^{6}$ Наиме, „разлагање семантичког садржаја лексема на његове семе омогућиће јасније уочавање принципа по којима се обележја одређеног појма хијерархизују у свести говорника индукујући нове садржаје" (ШтрБАц - ШтАсни 2017: 9). За одређење тих нових садржаја користи се термин појмовни домен, сродан термину концепт, али не и у потпуности идентичан, јер је одређење концепта отежано будући да је он у непосредној вези с блиским терминима као што су појам, представа и смисао (ЗыковА 2015: 56-60). Овом приликом је од важности својство концепта које садржи енциклопедијску информацију о одређеној појави или предмету и податак о њеној интерпретацији (ПоповА - Стерњин 2007: 34). С једне стране, концепти су мисаоне јединице, а са друге - то су елементи језичког

${ }^{5}$ Према схватању Ј. Најде, декомпозиција представља основну методу за анализу значења, и то издвајањем обележја од којих су изграђена значења речи. Он, такође, наводи компоненте значења глагола којима се означава кретање (окружење, извор енергије, кретање помоћу удова, тачке контакта са површином, редослед узастопних контаката између удова и површине, усмереност кретања) (NIDA 1975: 74-80).

${ }^{6}$ Теоријско становиште концептуалне анализе заснива се „на схватању ума као сложеног система који прима, складишти, проналази, преиначава и преноси информације. У оквиру когнитивне лингвистике значење се изједначава с концептуализацијом - образовањем појмова на основу човековог физичког, чулног, емоционалног и интелектуалног искуства о свету који га окружује" (ДрАгићЕвић 2007: 89-90). 
система помоћу којих се концепти вербализују. У том контексту значење језичких јединица сматра се делом концепта утврђеним језичким знаком у циљу комуникације, при чему се вербализују само комуникативно релевантни делови концепта.

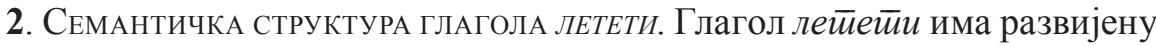
семантичку структуру, која је у РМС представљена са три значења. Његово примарно значење 1.а. 'кретати се у ваздуху, зраку помоћу крила или машина (о инсектима, птицама, авионима и сл.)' обухвата и подзначење б. 'возити се авионом, једрилицом и сл.; управљати тим апаратима'. Семантичким садржајем је, дакле, обухваћена архисема, која носи информацију о кретању. Од значаја је спецификована диференцијална сема високог ранга којом се детерминише простор одвијања радње (y вазgyxy), на основу које се глагол лет̄ейи сврстава у подгрупу глагола кретања према медијуму у којем се peализује. $^{7}$ Лексикографска интерпретација укључује и део тела птице помоћу којег се лети или пак мотора, машине која омогућава кретање ваздухопловног превозног средства. Подреализација у оквиру примарне реализације обухвата кретање ваздухом авионом, једрилицом и сл., али и управљање овим апаратима. Семантичка специфичност овога глагола произилази из обележја непосредног или посредног реализатора радње - животиња радом

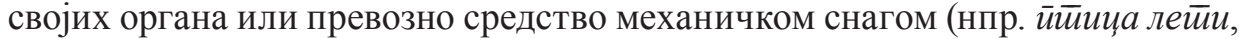
авион летии). А. Халас (2012: 293) наводи да се у речничкој дефиницији глагола лейей и јавила потреба за увођењем подзначења у оквиру основне реализације зато што човек није примарни, већ само један од могућих субјеката. ${ }^{8}$

Секундарна реализација 2.а. 'замахом бити бачен у ваздух, у зрак; бити разнет експлозивом’ веома је семантички блиска примарној реализацији будући да је између њих заступљена логичка повезаност на основу последичног кретања тела или делова тела у висину, кроз ваздух, што потврђује и устаљена конструкција (og)лейеӣu y вазgyx, са значењем 'експлодирати'. Подреализација б. ‘бити избачен с места, губити дотадашњи положај' мотивисана метафоричном асоцијацијом која се може одредити брзином нестајања из нечијег видокруга.

Значење под тачком 3. 'кретати се великом брзином, трчати, јурити; журити, хитати’ развијено је посредством метафоре будући да се кретање остварује на копненом простору и може се изразити поредбеним обрасцем 'креће се брзо као да лети’. Наиме, „брзина кретања, у смислу преласка одређеног простора за одређено време, јесте особина која је иманентна свим глаголима кретања. Свако кретање, обележено глаголом кретања, одвија се неком

${ }^{7}$ Сваком кретању је иманентан простор, правац и смер кретања. Простор као медијум кроз који се човек креће обично је спецификован већ у самом глаголу. Тако за кретање обележено глаголом хоgaйu знамо (подразумева се) да се одвија по земљи неком путањом, радња

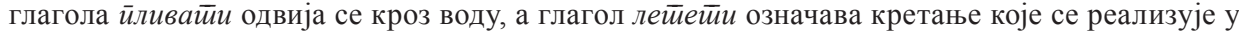
ваздуху (Vujović 2019: 11).

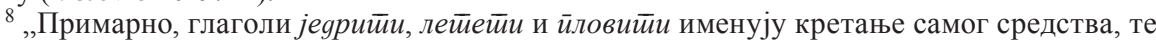
је у оквиру подзначења потребно нагласити и употребу у којој је човек субјекат, јер долази до измене у спецификацији средства у семској структури глагола, при чему летилице и пловила замењују своју функцију агенса функцијом средства којим се кретање одвија" (ХАлАс 2012: 293). 
својом брзином која се сматра просечном за ту врсту кретања" (VUJović 2019: 63). И када је реч о летењу птица или авиона, и оно се одвија просечном брзином за ту врсту субјекта, али га човек из своје перспективе доживљава, перципира као брзо, јер оно није брже или спорије од просека већ је брже од типичног људског кретања. Брзина кретања уграђена је као пратећа сема у семантички садржај лексеме летией и и семантичка реализација под 3. настала је на основу ње.

3. ДЕРИВАТИ ГЛАГОЛА ЛЕТЕТИ. Све богатство деривационог Потенцијала посматраног глагола најбоље се може представити приказом са дериватима распоређеним у деривационе низове. Двочлани деривациони низ чине мотивна реч и деривати првога степена (I), а вишечлани низови се састоје од деривата првог степена (I) и њихових даљих деривата - другог (II) и трећег степена (III).

\section{Двочлани низови}

I: лет-ај, лет-аш, лете-лац, лете-лица, лете-лиште, лете-ње, лете-ћи, лети-лац, лети-лиште, лет-ица, лет-кати, лет-ни, лет-нути; лети-ветар, лети-лист

\section{Вищечлани низови}

І лет-ø

II мимо-лет > III мимолет-но

І лет-ати > II лета-ње

II лета-лиште

II лета-ло

I лет-ач > II летач-ки

II летач-ице

I до-летети >II долет-ø

II долет-ати > III долета-ње

II долет-иште

II долет-нути

I за-летети / залетети се

II залет-ø > III залет-ни

II залет-ати се $>$ III залета-ње

II залет-авати се > III залетава-ње

II залет-ивати (се) > III залетива-ње

II залећ-ивати се

II залет-ач

II залет-ице

II залет-иште > III залетиш-ни

I из-летети

II излет-ø > III излет-ни

II излет-ати > III излета-ње

I над-летети

II надлет-ати > III надлета-ње

I на-летети / налетети се

II налет-ø

II налет-ати > III налета-ње

II налет-авати

I об-летети

II облет-ати > III облета-ње 
II облет-авати

II облет-ивати

I од-летети

II одлет-ø

II одлет-ати > III одлета-ње

І под-летети

II подлет-ø

II подлет-ати

I по-летети

II полет-ø > III полет-ан

II полет-авати

II полет-арац

II полет-ати > III полета-ње

II полет-ивати

II полет-уша

I пре-летети

II прелет-

II прелет-авати

II прелет-ати > III прелета-ње

II прелет-ивати

II прелет-ач > III прелетач-ки

I при-летети > II прилет-ати

I про-летети

II пролет-

II пролет-арац

II пролет-ати > III пролета-ње

II пролет-нути

I раз-летети се $>$ II разлет-ати се

I са-летети / салетети се > II салета-ње

II салет-љив

I с-летети / слетети се

II слет-ø > III слет-ски

II слет-авати (се)

II слет-ати > III слета-ње

II слет-иште

II слет-нути

І уз-летети / узлетети се

II узлет- $>>$ III узлет-ан

II узлет-авати

II узлет-ати (се) > III узлета-ње

II узлет-иште

I у-летети / улетети се

ІІ улет-ø

II улет-ати (се) > III улета-ње

Као што видимо, гнездо чине деривати различитог степена. Међу њима је 38 првостепених, суфиксала и префиксала готово исте продуктивности, другостепених има највише (61 дериват), при чему је у њиховој основи најчешће префиксирани глагол, док се деривати трећег степена, очекивано, јављају у најмањем броју (21) и то су по правилу глаголске именице, јединице с граматичким значењем. Оваква структура гнезда с глаголским мотиватором 
указује на његов висок деривациони потенцијал, што свакако јесте последица његовог семантичког садржаја, односно његове денотације везане за феномен кретања, које има свој почетак, трајање и завршетак, а што се у српском језику формализује префиксираним облицима. ${ }^{9}$

4. Полмовни домени. Појмовни домени идентификовани су на основу семантичких реализација деривата обухваћених гнездом с мотивном речју лет̄ети $и$. Међу њима су чести они са развијеном семантичком структуром. Код вишезначних деривата свака посебна реализација распоређена је у одговарајући појмовни домен, што значи да ће се поједини деривати наћи у више различитих домена. Деривати префиксираних глагола наводе се уз њих у загради код примарног значења будући да припадају истом домену - имперфективни и итеративни, као и глаголске именице. ${ }^{10}$

Ипак, дистрибуција по појмовним доменима не може се сматрати потпуно прецизном будући да у њиховим реализацијама, како примарној тако и секундарним, коегзистирају различите компоненте, а припадност домену условљена је оном која се сматра доминантном, на пример глагол узлетиейu у реализацији 1.б. 'нагло појурити навише, брзо се попети' садржи компоненту усмереног кретања према горе, која се може схватити као перлативна, али и као аблативна, као што има и субитивно обележје, које се може одредити као доминантно.

4.1. Домен РАДњЕ. Доменом радње обухваћени су деривати у чијој су концептуалној вредности заступљене семантичке компоненте којима се износи информација о обављању какве активности или радње. То су на првом месту деривати који су према свом значењу најближи појмовној вредности мотивног глагола, и то у његовој примарној реализацији, која подразумева кретање у ваздуху и којима се означавају фазе процеса или радње које су иначе уобичајене за глаголе кретања, као што су то ингресивност, аблативност, адлативност, перлативност. Ови глаголи углавном су настали префиксацијом, а својим секундарним реализацијама уклапају се у различите поддомене домена радње, као што је, на пример, говорење, па и интелектуални процеси, или радње које се остварују неком друштвеном интеракцијом. Стога је овај домен хетероген, а семантичка типологија деривата указује на значај који у значење деривата уносе, у првом реду, префикси, којима се модификује

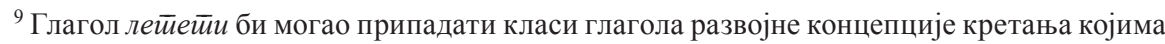
се именује радња у својој развојној фази, али је „његова континуирана процесуалност ограничена тренутком досезања одређенога циља или резултата" као код глагола $u \hbar u$ и воguт̄u (АлАновић 2013: 44).

${ }^{10}$ Префиксација је веома продуктиван процес у творби јединица које су мотивисане глаголом. Са деривационог становишта примарним образовањем сматра се перфективни глагол, док је са вишим деривационим степеном његов имперфективни, често и итеративни облик, у чијој је творбеној структури основа перфективног префиксираног глагола и суфикс,

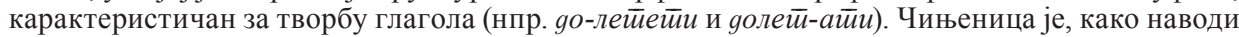
А. Рађеновић (2016: 286), да ,аспект не исказује објективно временско својство (да ли глаголска радња траје, да ли има или нема крај и сл.) већ на који начин говорник посматра радњу: као јединствену целину или процес", што се у знатној мери рефлектује на деривационом, а самим тим и на лексичком плану. 
значење мотивног појма лет̄ети $и$, али и значај семантичких компоненти које се активирају у стварању секундарних значења деривата, као што су то оне којима се означава усмереност или брзина кретања.

\subsection{1. Кретање у ваздуху или по земљи одређеном путањом}

Највећим бројем деривата у њиховој примарној реализацији означава се кретање како у ваздуху тако и по земљи одређеном путањом (72 деривата од укупно 121 или 59,5\%). То су глаголски деривати настали суфиксацијом (3) и, знатно чешће, префиксацијом (43) те од њих већином изведене глаголске именице (26). Стога је овај домен најразвијенији и указује на значај архисеме 'кретање', али и диференцијалне семе високог ранга којом се износи информација о простору у којем се кретање одвија.

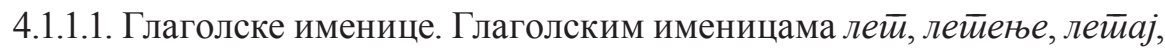
дериватима првога степена, углавном се формализује исти семантички садржај као у мотивном глаголу, с тим да се ове јединице не би могле сврстати у низ творбених дублета јер дериват леш̄-ø има богатији семантички садржај чак и од мотивног глагола те сходно томе надмашује дериват с граматичким значењем и остварује ширу семантичку структуру: 1. 'кретање у ваздуху помоћу крила или машина'; 2. фиг. 'врло брзо кретање'; 3.а. 'кретање по ваздуху нечега што је бачено'. б. фиг. 'занос, одушевљење'. 4. пом. 'окретање једрењака ради прихватања ветра с другог бока'. Глаголска именица лейење (лијейење), у чијој је структури суфикс -ње, присутан и у

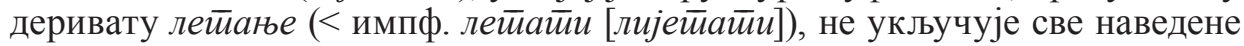

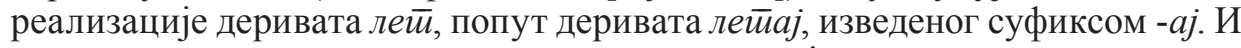
глаголска именица залей секундарном реализацијом припада домену радње, односно кретања по земљи - 2. 'брзо трчање ради замаха пред скок или пред бацање чега'. ${ }^{11}$

4.1.1.2. Глаголи с ингресивним значењем. Носилац ингресивности може бити суфикс, као у деривату лет̄нуйu, у чијем је склопу деминутивни суфикс -нуйи, мада се њиме не означава деминуција, већ почетак вршења радње ‘полетети, одлетети'. Ингресивно значење убрзаног кретања, али сада на копненом простору, овај глагол има и у реализацији 2.'појурити, јурнути, потрчати'.

Ипак, неупоредиво је продуктивнија њихова творба префиксацијом, при чему је префикс семантички маркер ингресивности. ${ }^{12}$ У структури ових

${ }^{11}$ Б. Ковачевић истиче мешовити карактер глаголских именица и констатује да неке именице имају више, а неке мање глаголских карактеристика. „На једном крају континуума су глаголске именице које су у правом смислу име радње која је означена глаголом, именице из класе nomen actionis. На другом крају су у потпуности лексикализоване глаголске именице, које су постале йраве именице, пошто не поседују никакве глаголске особине (ни семантичке, ни синтаксичке, ни морфолошке), а са глаголом их повезује њихово глаголско порекло"

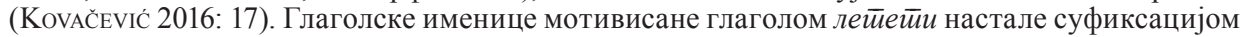
на основу свог значења више се уклапају у другу групу, док оне које су настале у даљем деривационом акту од префиксираних глагола више припадају првој групи глаголских имени-

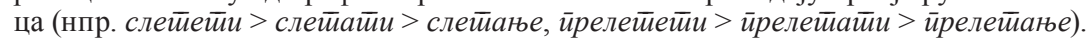

12 Улога префикса у творби глаголских деривата (префиксала) може бити двојака: граматичка, при чему утиче на промену глаголског вида, и своди се само на перфективизацију 


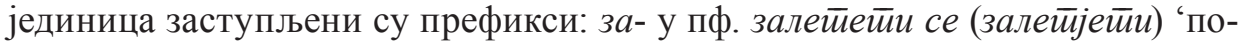
чети летети; отпочети брзо покрет, затрчати се, појурити, полетети' (> импф.

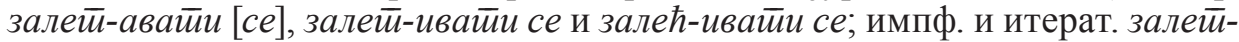

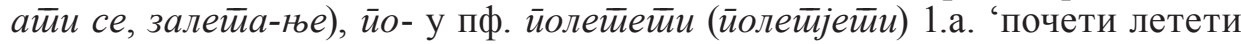
крилима по ваздуху, управити свој лет неком смеру, одлетети'; б. 'почети се

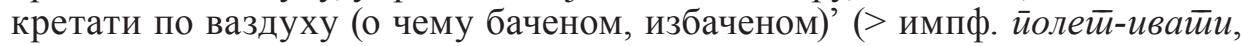

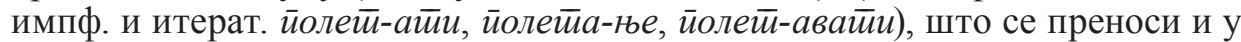
значење 2.а. 'почети се брзо кретати по земљи'; б. 'брзо се покренути, по-

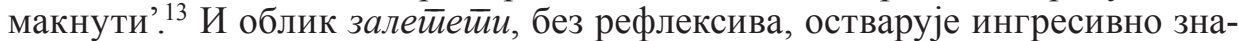
чење у реализацији 3. 'натерати да почне летети, подстаћи да лети, да јури'.14

У садржају префиксала узлет̄ети с се 'почети трчати, растрчати се узнемирено’ коегзистира ингресивност и кретање које се одвија из центра ка периферији, али у различитим правцима. Према свом значењу овај префиксал припада глаголима кретања, али се њиме означава почетак убрзаног кретања по тлу, што је показатељ његове фигуративне реализације.

4.1.1.3. Глаголи с аблативним значењем. Ови глаголи настају употребом префикса $u з$-, og-, $\bar{u} о$ - или $y$ - уз мотивни глагол летие $\bar{u} u$, који модификују његово значење уношењем аблативне компоненте 'удаљавања од почетне

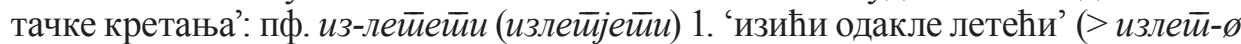

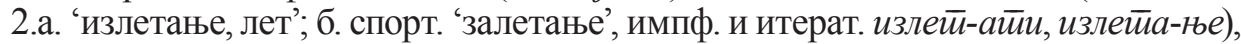

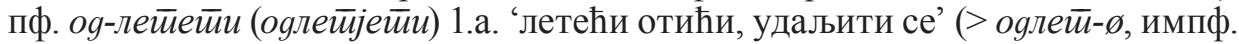

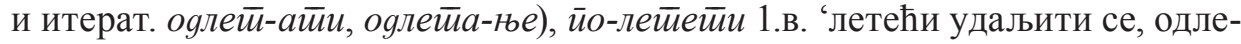
тети', 3. 'нагло се уздићи, сунути, винути се' (> йолей-ø 1. 'замах код узлета, почетак лета, полетање онога што може летети', импф. и итерат. $\bar{u} о л е \bar{u}-a \bar{u} u$,

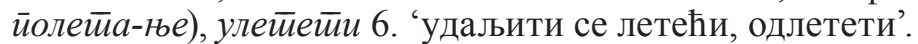

Значење префиксала у чијој је структури префикс og- такође се подудара с његовим предлошким аблативним значењем 'одвајање, напуштање, удаљавање', што је видљиво и у значењу глагола оgлейейu 3. 'при брзом покрету отпасти, откинути се'. Када је у саставу глагола префикс чија примарна и системска функција није стварање аблативног значења, таква реализација префиксала заузима периферно место у његовој семантичкој структури, као у случају глагола улетиейи.

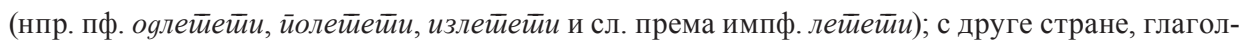
ски префикси могу модификовати и основу, а та модификација може бити и лексичка ако задире дубље у семантику основе. В. Миљковић сматра да су „обе идеје - и она о префиксу као модификатору и она о префиксима који носе чисту граматичку информацију - продукт теоријског приступа који феномену глаголске префиксације прилази постављајући у центар пажње саму основу и дефинишући улогу префикса у односу на њу, па који, стога, можемо окарактерисати као основоцентризам" (MiLJKović 2018: 154). Овом приступу иде у прилог и то што се префиксирани перфективни глаголи понашају као индуктори нових имперфективних глагола насталих у даљој деривацији суфиксацијом (нпр. импф. летие $\bar{u} u>$ пф. $\bar{u} о-л е \bar{u} е \bar{u} u$ $>$ импф. $\bar{и} о л е \bar{u}-a \bar{u} u)$.

13 Другачија пак значења овај префиксал остварује у реализацијама 5.б. 'срушити се, бити сасут'; в. 'бити бачен (некуда), бити избачен, избијен, истргнут'; г. 'отпасти, изгубити ce', која би се могла окарактерисати као радња с манипулативним значењем.

14 У овом облику и оствареном значењу глагол залетиет̄u је транзитиван, што је показатељ утицаја семантичке реализације на промену обележја глаголског рода, будући да су глаголи кретања превасходно интранзитивни. 
Код глагола̄ са секундарном реализацијом којом се они такође уклапају у глаголе кретања, али сада у промењеном медијуму, заступљена је компонента убрзаног или наглог реализовања радње: излететей 2. фиг. а. 'изићи трком, брзо истрчати', па и у реализацији д. 'нагло изаћи, утећи, измакнути се, отети се'; оgлететеи и 1.б.'отрчати, одјурити’.

4.1.1.4. Глаголи с адлативним значењем. Кретање усмерено ка одређеном циљу исказује се глаголима у чијој је појмовној вредности заступљена компонента 'стизања, доласка до неке тачке у простору', а такво усмерено кретање које у себи садржи и циљ - одражава адлативан однос између субјекта и локализатора. Деривиране јединице са адлативним значењем мотивисане глаголом леиеетии стичу ово обележје употребом префикса који у значење деривата уносе компоненту адлативности, која подразумева и обележје резултативности. Типичан префикс којим се у дериват уноси адлативна семантика јесте префикс gо- 'стићи до циљне тачке у простору' - пф. gо-летией (gолеијјешии) 'летећи доћи, приспети, појавити се где, стићи, доспети' (>

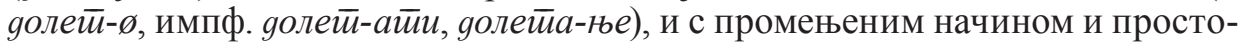
ром кретања у значењу 2. 'јурећи, трчећи, доћи, дотрчати, дојурити'. Поред овог префиксала, ту су и они у чијој је структури префикс $\bar{u} p u$ - у пф. $\bar{u} p u-л е-$

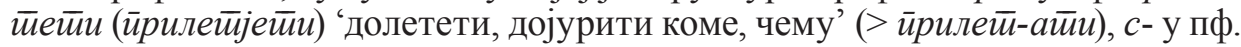
слетеети 'летећи спустити се на тло; пасти', са истим значењем у измењеном окружењу 2.а. 'стрчати, јурнути наниже', па и у значењу 4. 'пасти, стропоштати се' и слетеиеии се 'долетети на једно место, са разних страна, дојурити', са значењем које подразумева завршетак радње са периферије ка центру, уз

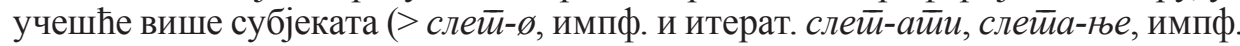

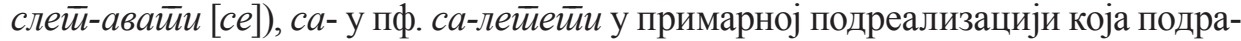
зумева извршење радње по тлу 1.в. 'прискочити, дотрчати', а у секундарном значењу у ваздуху 2. 'слетети'. Са морфемом се овај глагол подразумева више учесника чије је кретање усмерено из различитих тачака, а завршено у једном центру 'скупити се, стрчати се са свих страна'. Префикс уз- у пф.

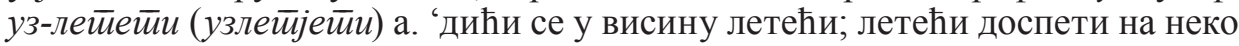
узвишено место' такође доприноси стварању адлативног значења (> узлети-

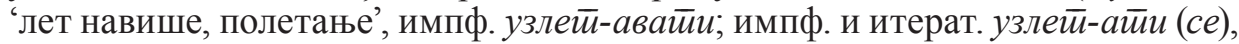
узлейа-ње).

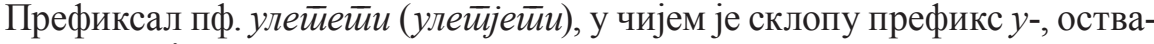
рује значења којима се денотира завршетак радње у унутрашњости локализатора, као у значењу 1. 'ући летећи'; 2. 'ући у највећој брзини, дојурити' (> импф.

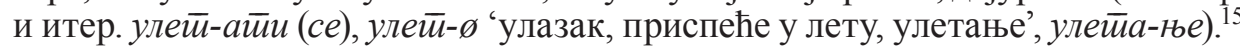
Адлативно значење кретања по земљи глагол улеиеейи има под тачком 2. 'ући у највећој брзини, дојурити'.

4.1.1.5. Глаголи с перлативним значењем. Овим глаголима се означава прелазак преко површине локализатора, од почетне до крајње тачке које се налазе на границама локализатора. С таквим значењем је перфективни пре-

15 Префикс $y$ - у глаголе кретања уноси компоненту којом се означава завршетак радње у унутрашњости локализатора, те је њихово примарно обележје интралокализација, а у ширем смислу они су и глаголи са адлативним значењем (VuJović 2019: 112). 


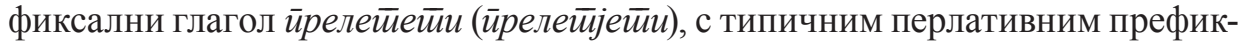
сом йре- и са примарним значењем 1.а. 'летећи помоћу крила прећи какав простор'. б. 'летећи проћи, пројурити, прелетети изнад кога, чега', па и у значењу које укључује и резултативност радње и контакт с горњом површином локализатора под тачком 5. 'летећи пасти даље од мете, циља' (> йрелей-, ,

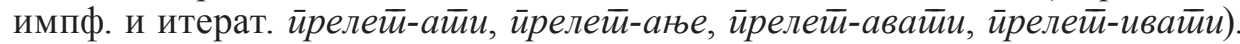
Са истом концептуалном вредношћу је и префиксал мимолет' 'прелет, прелаз летом'.

Према наводима Д. Вујовић (2019: 40), перлативна концепција кретања заступљена је и код глагола којима се означава пролазак кроз унутрашњост локализатора, као и пролазак поред или око локализатора, што може укључити и кретање изнад или испод, испред или иза локализатора када су у питању префиксали мотивисани примарним значењем глагола лейейи.

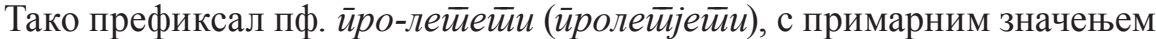
'летећи проћи крај, мимо кога, чега, изнад кога, чега' (> $\bar{u} р о л е \bar{u}-\varnothing$, импф. и итерат. $\bar{и} р о л е \bar{u}-a \bar{u} u, \bar{u} р о л е \bar{u} a-њ e)$, одређује на основу семантике префикса üро- кретање које се одвија поред или изнад локализатора.

У структури глагола са значењем 'кретати се иза локализатора', тј. кретања које је усмерено ка задњој спољашњој страни локализатора, налази се

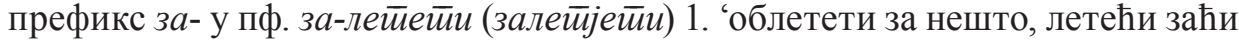

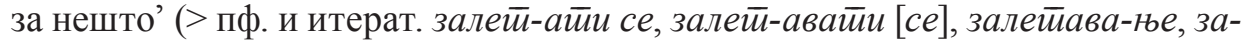

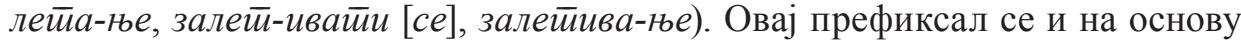
својих секундарних реализација уклапа у посматрани појмовни домен тако што у реализацији под тачком 2 . префикс за- уноси значење кретања које се одвија нежељеним смером и губљењем оријентације у ваздушном простору 'летећи заћи куда, скренути, залутати'. Слично значење остварује и глагол с префиксом об-, који у семантички садржај префиксала уноси компоненту

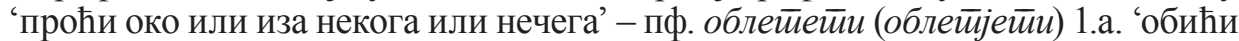
летећи или брзо крећући, оптрчати'; б. ‘заобићи летећи’ (> импф. облей-ава-

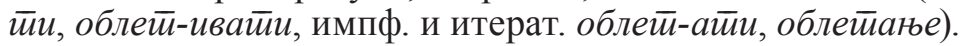

Кретање у ваздуху усмерено испод локализатора формализује се пре-

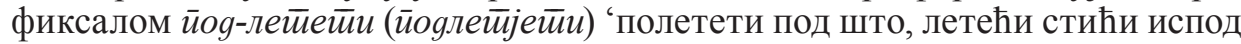

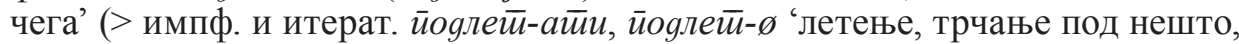
прилажење'), што је последица семантике префикса $\bar{u} о g-$-, која кореспондира са значењем предлога $\bar{u} о g$.

Префиксалима се формализује и кретање изнад локализатора, у висину, као последица значења које у њих уносе префикси нag- у наgлетеиейи (наgле-

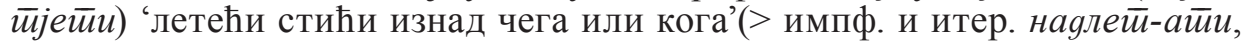
наgлетиа-ґе). Овај префиксал припада истом домену и на основу своје секундарне реализације 'престићи у летењу'. И глагол йрелетией $и$, са префиксом upe-, на основу секундарног значења 2. (кога што) а. 'ваздухом проћи изнад кога или чега' припада категорији перлативних глагола. Имперфективни

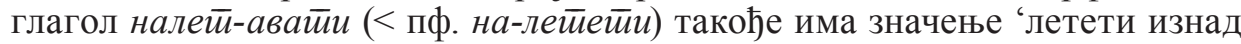
чега, надлетати што'.

Специфичније је значење које је у оквиру семантичке структуре пре-

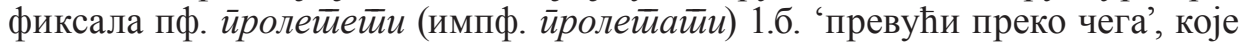
подразумева извршење радње на површини локализатора с једног његовог 
краја на други, чиме се остварује обележје перлативности, али оног кретања која се не одвија у ваздушном простору.

4.1.1.6. Глаголи са значењем дифузног кретања. У дифузне су сврстани глаголи са значењем кретања које се одвија у различитим правцима, из центра ка периферији, при чему се подразумева учешће више субјеката. С таквом

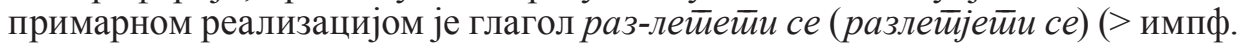

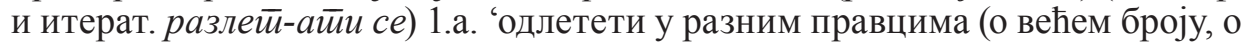
јату); разићи се брзо, журно на разне стране'; б. 'расути се, растурити се, распршати се'. У секундарном значењу овога глагола 2.а. 'почети летети тамо-амо, ударити у летење' префикс раз- доприноси стварању значења каквог бесциљног кретања са ингресивном компонентом, као и у значењу које подра-

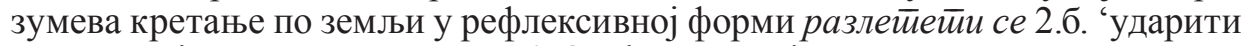
у трчање, јурњаву, растрчати се’. Овој категорији глагола може припасти и

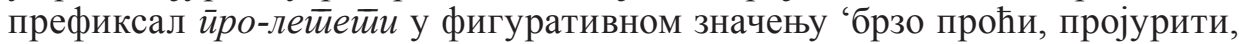
ширећи се на све стране'.

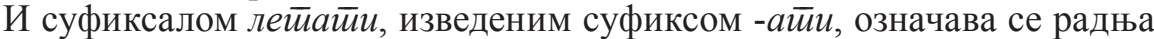
која се може окарактерисати као бесциљна, са честом променом правца кретања 'летети тамо-амо', а по земљи и у секундарној реализацији са ознаком фигуративно 'трчати, јурити тамо-амо'.

4.1.1.7. Глаголи с деминутивним и/или континуативним значењем. Гла-

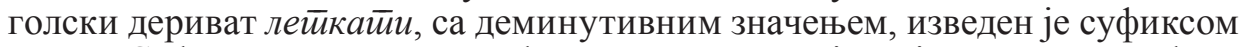

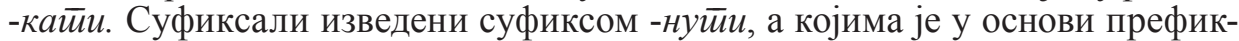

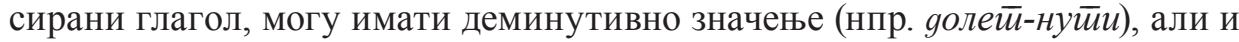
значење које се може одредити као континуативно јер се њима означава

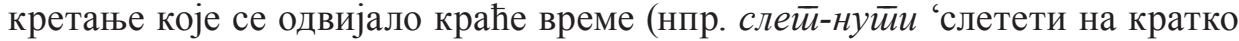
време, на тренутак'). Овим глаголима одговара парафраза 'провести неко време у кретању исказаном мотивним глаголом’ (VUJoVIć 2019: 101).

4.1.1.8. Глаголи са субитивним значењем. Субитивним глаголима означава се активност која се изненадно појављује, као у деривату $\bar{u} р о л е \bar{u}-н у \bar{u} u$

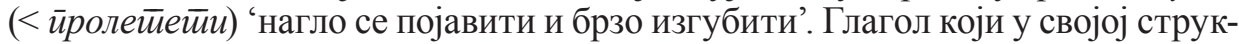
тури садржи префикс на- остварује значење случајног контакта са неком препреком на путу, таквог који се може сматрати субитивном радњом - на-

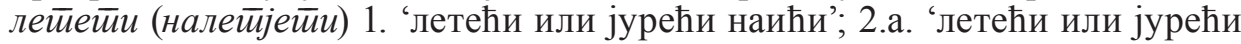
случајно наићи (на некога, на нешто); сударити се (са ким, чим)' и под тачком 3.б. 'нахрупити, упасти, улетети' и 4. 'нагло се навући, намаћи на што (> налей-ø 1. 'лет према неком циљу, изнад нечега, наилазак у лету; напад из лета'; 2.а. 'насртај, навала; јуриш'; б. 'снажан наступ, прилив нечега; снажан замах: ветра, ватре'; па и у фигуративном значењу 3. 'онај који је жесток,

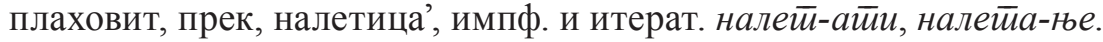

Са промењеним простором и средством реализовања радње, али са компонентом субитивног карактера, јављају се и префиксали улетиейи (уле$\bar{u}$ jeūu) у значењу 3. 'неочекивано, изненада ступити, ући; упасти', залетиети

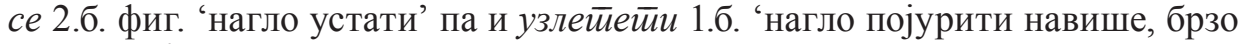
се попети' - са кретањем усмереним према горе, али и са кретањем усмере-

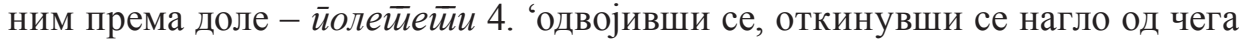
пасти на земљу, срушити се' и у значењу 5.а. 'нагло потећи, шикнути'. 
Субитивна компонента заступљена је и у секундарним значењима префиксала излетеиеии 2.г. 'нагло избити, јурнути, провалити'; 2.е. 'нагло се појавити, изићи', ирролетемети (йролет̈јетии) 3.а. фиг. 'нагло се појавити и ишчезнути, синути'; слететеи се 2. 'нагло надоћи, навалити, наврети' и $c a$ летеией се 2. 'нагло надоћи, навалити, наврети'. Ово семантичко обележје заступљено је и у глаголу налеиеетии у значењу 2.б. 'неочекивано, изненада срести се с ким, набасати на некога: на заседу', као и у префиксалима разлететеии се 3.а. 'нагло се растворити, расклопити' и узлетеией б. 'нагло појурити навише, брзо се попети'.

4.1.1.9. Сативни глаголи. Ово значење има само једну потврду: глагол с префиксом на- и морфемом се-налететеии се-остварује сативно значење 1. 'провести много времена летећи, заситити се летења'.

4.1.2. Радње у домену друштвених односа. Мотивни глагол летееиии поприма значења апстрактног типа, којима се углавном концептуализује човеково понашање у неком виду друштвених односа, и то посредством метафоричних асоцијација, којима је углавном у основи компонента повећане брзине кретања $\rightarrow$ непромишљен, нагао поступак, одлука и сл. Они се одликују семантичким садржајем који подразумева или укључује компоненту којом се квалификује:

а) какав поступак на индивидуалном плану, уз имплицитно подразумевану интеракцију са другом особом: залететеи се 3. фиг. 'пренаглити, непромишљено поступити';

б) какав поступак на индивидуалном плану, уз експлицитно подразумевану интеракцију са другом особом: облетиайи (облијейайи) 2. фиг. 'трчати, мотати се око кога ради постизања неког циља, удварати се'; узлетиетии

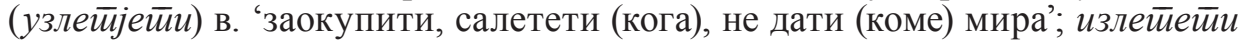
1.ђ. 'нагло напустити, оставити кога';

в) позиција или положај особе обично у друштвеном или радном окружењу: излетеиеии 1.б. 'ненадано и нагло испасти из чега, бити избачен'. в. 'бити искључен, удаљен одакле, из чега'; оgлетеети и 2. фиг. 'бити смењен с

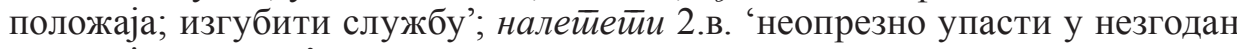
положај, натрчати';

г) физички обрачун с неким: налетееиеи 3.а. 'ударити (на кога, на што)

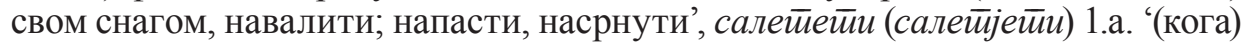
заокупити, напасти кога, навалити, насрнути на кога'.

4.1.3. Радња говорења. Међу глаголима с мотивном речју летеиети иаступљени су они којима се означава вид вербалне продукције, обично недоми-

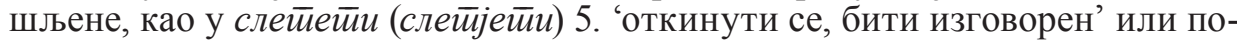
вршне, као у йрелетеией 4.д. 'додирнути се, дотакнути се у говору'. Овој категорији припадају и глаголи којима се означава и вид вербалне интерак-

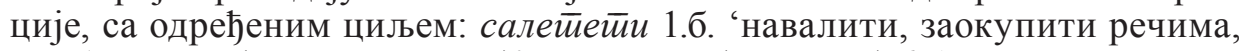

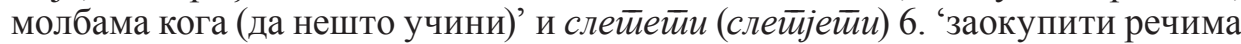
некога да нешто учини, салетети', или нарушавање правила реда говорења

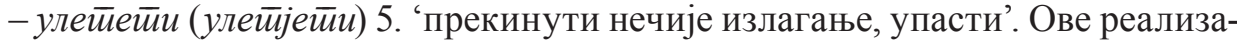
ције су такође индуковане метафором, активирањем компоненте брзине и 
кретања више субјеката из различитих праваца (у овом случају субјекти су репрезентовани речима).

4.1.4. Интелектуалне радње. Значење интелектуалне радње остварује се као секундарна реализација у префиксираним глаголима, уз активирање компонената које квалификују овај процес као изненадан, неочекиван, као у глаголу облетеиети $и$ 2. ‘доћи, пасти на ум, заокупити' или компоненте која носи информацију о убрзаном процесу, који се одвија у краћем временском периоду од уобичајеног, као у глаголу йрелететей 4. фиг. а. 'брзо, на брзу руку, површно прочитати, прегледати што'; 4.г 'брзо у мислима проћи, обновити, представити прошле догађаје'. И ове реализације су метафоричног типа.

4.2. Домен стАњА. Овом домену припада 5 деривата (4,13\%). Глаголима с мотивном речју летеиети $и$ може се концептуализовати и одређено стање - сале$\bar{u} е \bar{u} и$ 1.г. фиг. 'обузети, спопасти (сан, мисао и сл.)', при чему су активне имплицитне компоненте које подразумевају невољно, спонтано и дуготрајно стање. Овом домену би се могли придружити и глаголи чије се значење може довести у везу с појавношћу одређеног феномена, са настајањем, као у фигу-

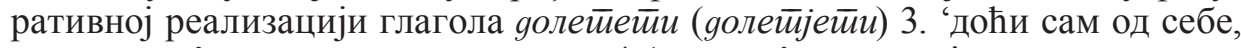
створити се', али и у његовом значењу 4. 'настати' или нестајањем, као у глаголу слетеиеи и фигуративном значењу 2.б. 'нестати, ишчезнути с неке површине'.

Глагол разлететей се у својој подреализацији под тачком 2.б. 'предати се каквом послу интензивно, журећи’ садржи доминантну компоненту радње, која укључује и компоненту стања, те би стога могао бити део овог лексичког скупа, донекле и у значењу 3.б. 'разбити се на комаде, распасти се'.

Глаголском именицом залет̄ такође се концептуализује стање, и то њеним секундарним значењем које је означено као фигуративно 'размах; нагао развитак'.

4.3. ТЕмПоРАлни домен (два деривата, односно 1,65\%). Темпорално значење остварено је у оквиру семантичке структуре префиксала йролетиейи 3.б. 'брзо проћи, протећи, минути (о времену)', са истим значењем и йреле$\bar{u} e \bar{u} u$ под тачком 4.в., при чему је значајна компонента убрзаног и невидљивог протока (условно или апстрактно схваћеног кретања).

4.4. Домен просторА. Међу јединицама којима се формализује простор с мотивним глаголом летеиеии (9 деривата, односно 7,44\%) заступљени су деривати првог степена, са фонолошки различитим основама и суфиксом -лищйе у својој структури: летиа-лищйе (лијетиалищйе) 'место летења' и са

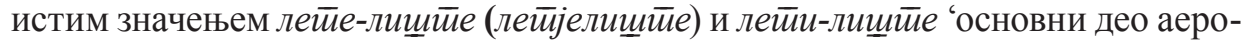
дрома на коме је простор за узлетање и слетање авиона'. Између деривата и мотивне речи успоставља се метонимијски трансфер по моделу $\mathrm{X} \rightarrow$ место на коме се одвија $\mathrm{X}$, при чему је $\mathrm{X}$ назив мотивне радње. Дериват првог степена с просторним значењем изведен је и суфиксом -ища у летици 'путања по којој нешто лети'.

Један број другостепених деривата из ове тематске групе мотивисан је

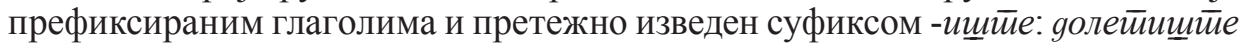

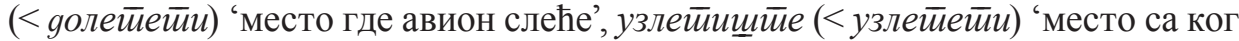
узлећу, полећу авиони, аеродром; полетна површина на аеродрому, писта'. 
Са широм семантичком структуром којом су обухваћена просторна значења

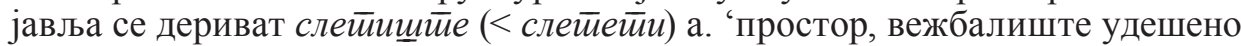
за слетове'; б. 'место нарочито удешено за слетање авиона'. Спортској тер-

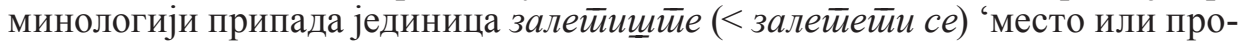
стор на коме се узима залет’, а дериват залей, изведен нултим суфиксом, има примарно значење просторног типа 'место куд се пчеле залећу, куд обично лете; правац летења'.

4.5. Домен животињА. Глаголом лет̄етии мотивисано је 10 зоонима (8,26\%), којима се именују животиње којима је радња њиме именована њихово иманентно својство, на основу којег се разликују од већине других животињских врста. Дакле, дериватима се именују птице које не припадају некој посебној врсти или породици већ према способности, трајању летења, и то као општи назив за више врста птица које издржавају дуге летове летиячице, што је и зоолошки термин изведен суфиксом -ица (мн.) додатим на првостепени дериват лет̄ач. На основу своје примарне реализације 'птица која може дуго

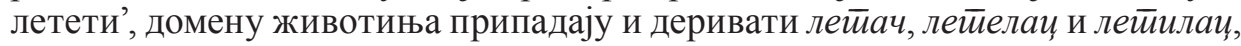
у чијој је структури суфикс - ач односно -лач, као и лейелица, изведен суфиксом -лица и са значењем 1. 'птица која издржава дуг лет'. Овом домену

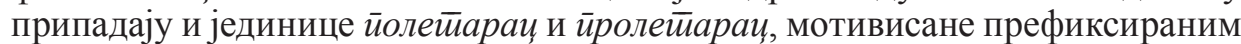

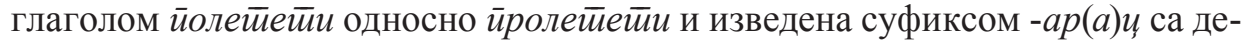
минутивним значењем 'птић који је тек почео летети', као и сложеница

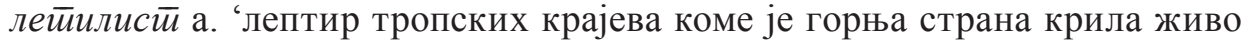
обојена'; б. 'инсекат тропских крајева из пор. Plasmidae зелених крила као лист Phyllium siccifolium'.

Регистровани су и деривати којима су именоване животиње способне да лете, али које не припадају птицама, као што је то лет̄ащu, изведен суфиксом -au, такође са својством термина којим се означава 'врста сисара који може летети Petaurus', као и йолейущua, дериват који је у секундарном значењу назив за морску рибу, индукован метафоричном асоцијацијом заснованом на карактеристичном изгледу птице, јер ове рибе имају и назив ластавице, а њихова основна карактеристика је то што су им се прсне и трбушне пераје развиле у облику крила помоћу којих могу искачући из мора ваздухом прећи удаљеност од преко 300 метара и задржати се у ваздуху до 40 секунди. ${ }^{16}$

4.6. Домен човекА. Овом домену припада 7 деривата (5,79\%). Поред јединица агентивног типа, којим се означава човек који реализује радњу именовану мотивним глаголом у својим секундарним реализацијама: летиач, лейелац и летиилац 2. 'пилот у авиону', по законитости метонимије типа $\mathrm{X} \rightarrow$ особа која X-ује, управља летом авиона - развили су се и деривати који се такође могу одредити као агентивни, али и са атрибутивним примесама, као у примеру са ознаком необично залейач 'онај који се залеће', мотивисаном префиксираним глаголом залеӣeӣu ce, вероватно његовом секундарном реализацијом 'пренаглити, непромишљено поступити' и изведеном суфиксом - $а ч$, као и у деривату йрелет̄ $а ч$, незабележеном у РМС али данас веома фреквентном, који се може маркирати као ироничан, са атрибутивним зна-

${ }^{16}$ https://hr.wikipedia.org/wiki/Poletuše. 
чењем 'особа која лако напушта неку идеју, или нешто што воли, и прелази у супротан табор, углавном из материјалне или неке друге користи'. Са

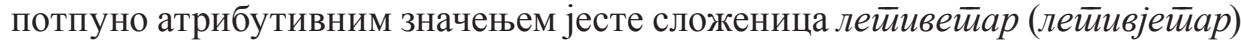
'ветрогоња, ветропир'.

Са сложенијом семантичком структуром потврђен је дериват йолейищuа, такође мотивисан префиксираним глаголом йолетиети и и изведен суфиксом -ущца. Примарна реализација, означена као необична, гласи 'она која лети'. У дериват се вероватно преноси секундарна реализација мотивног глагола 2.а 'кретати се великом брзином, трчати, јурити; журити, хитати'.

4.7. ДОМЕН ПРЕДМЕТА. У домен предмета сврстане су три лексеме $(2,48 \%)$. Будући да се ваздухопловна средства одређују као апарат, она свакако припадају предметном домену. Њихова основна функција јесте кретање кроз ваздушни простор, те је веза с мотивним глаголом потпуно прозирна и метонимијског је типа. Деривати су првога степена и изведени суфиком -ло у летиало (лијетиало) 'апарат за летење' или суфиксом -лища у дублетним облицима лететелиц односно летиилии,${ }^{17}$ који се својим секундарним значењем уклапају у посматрани домен 'авион и други који апарат направљен за летење'.

4.8. Домен осоьинЕ. У домен којим се обухватају деривати са значењем особине уклапа се 9 јединица (7,44\%). Придевским образовањима мотивисаним глаголом летеиейи може се изразити одређени квалификативни садржај, као дериватом, попридевљеним глаголским прилогом садашњим, летеиећ 'који се не задржава дуго на једном месту, пролазан, привремен: гост, посетилац' или придевом салешиљьи, мотивисаним префиксираним глаголом салетеиеи и и изведеним суфиксом -љив 'који салеће, заокупља, наваљује питањима, молбама и сл.', који денотира особину карактеристичну за човеково понашање. Ту спада и придевски дериват узлешиан, мотивисан префиксираним глаголом узлетеиети $u$ и изведен суфиксом -ан 'способан да полети навише, живахан, полетан'. Сам придев йолет̄ан, такође мотивисан префиксираним глаголом йолетиетии, има два значења - примарно, којим се изражава намена 'који служи за полетање, полет: перје, писта' и секундарно, квалификативно, метафорично 'који за чим радо лети, похлепан, пожудан'.

Овом домену припада и прилог залейище, који је такође с префиксираним глаголским мотиватором у основи залететеии се и са квалификацијом начина на који се радња врши 'са залетом', као и прилог мимолейно 'узгредно у лету, летимично'.

Иако су релациони придеви као деривати у првом реду с граматичким значењем, они ипак својим семантичким садржајем одражавају концепт особине. Ови придеви су различитог деривационог степена, што је, наравно, условљено деривационим статусом мотивне речи која ће се наћи у њиховој творбеној основи. То су претежно деривати другога степена: летиачки, изведен суфиксом -чки (<лемач) 'који се односи на летаче и летење', затим придев лет̈ни, изведен суфиксом -ни 'који се односи на лет, који омогућује летење'.

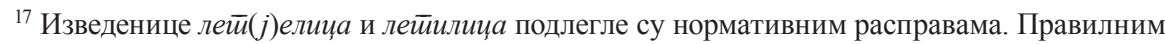
обликом сматра се дериват лейелиц̧а (ШипкА 2000: 246). У дериватолошком смислу овде је важна идентификација форманата у саставу датих деривата. Питање је да ли су они изведени суфиксом -ица од основе радног глаголског придева, или је то пак суфикс -лиц̧а, односно -илицุa. 
Остали релациони придеви припадају микрогнездима у којима су мотива-

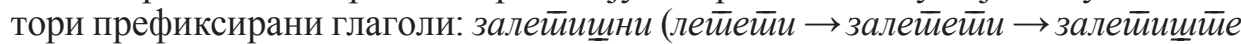

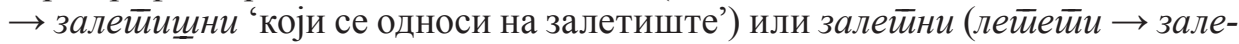

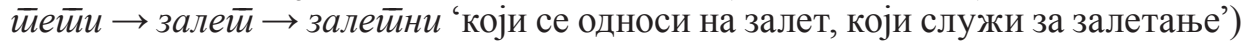

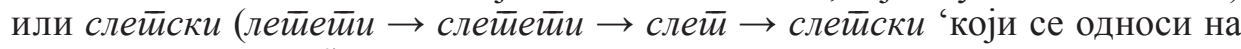
слетове: програм').

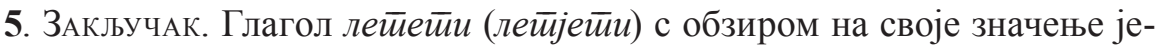
динствен је у лексичком систему српског језика и не постоји семантички нити творбени кореспондент којим се формализује кретање у ваздуху помоћу крила код птица или снагом погона код летелица. Он је, дакле, базична јединица у значајној категорији глагола кретања, издвојен од других из исте парадигме на основу простора у којем се радња односно кретање одвија.

У истраживању смо пошли од претпоставке, која се показала тачном, да секундарне реализације у оквиру полисемантичне структуре глагола ле$\bar{u} e \bar{u} u$ представљају индикаторе основних појмовних домена у које hе се на основу својих примарних, али и секундарних реализација у највећем броју уклапати и деривати мотивисани овим глаголом. Тако секундарне реализације глагола лет̄ей $и$ припадају домЕну РАДњЕ, и то кретања, метафоричког типа на основу семе брзине - кроз ваздух или по земљи, али под утицајем метафоре и радње везане за друштвени или пословни контекст. Деривати који припадају овом гнезду последица су семантичког садржаја мотиватора, не само оних компоненти које су експлицитно садржане у његовој лексикографској интерпретацији (медијум кретања, субјекат - птица или авион) већ и оних које су имплицитног карактера (усмереност и брзина, па и начин на који визуелно перципирамо летење).

Најобимнији, истовремено и вишеслојан, јесте дОмЕН РАдњЕ, будући да

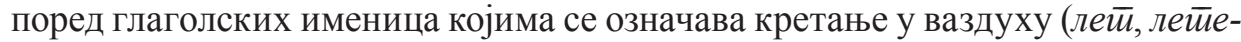

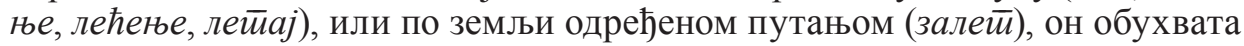
и јединице из поддомена којима се означавају фазе у развоју радње, попут

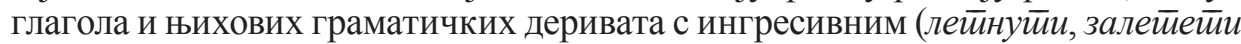

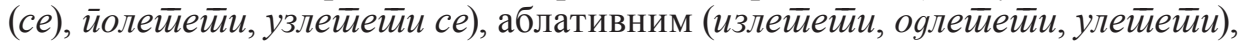

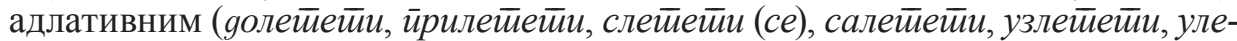

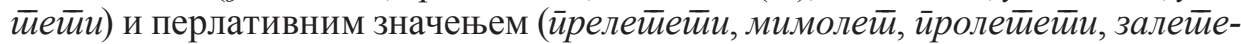

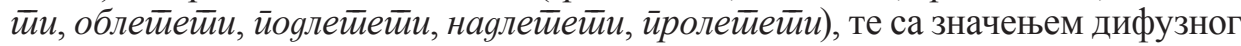

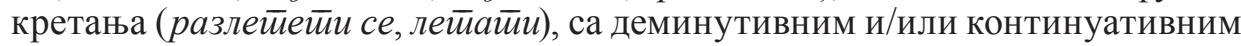

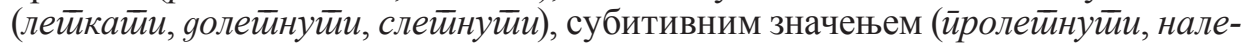

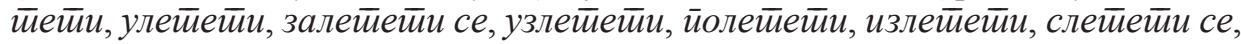

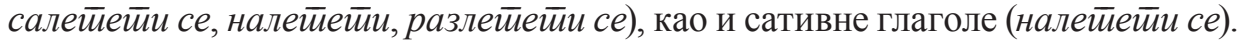
Посебне поддомене чине деривати којима се концептуализује радња као последица одређених, углавном негативно вреднованих друштвених односа

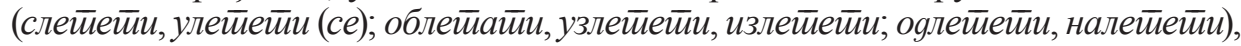
насталих посредством метафоре, као и јединице из семантичке категорије

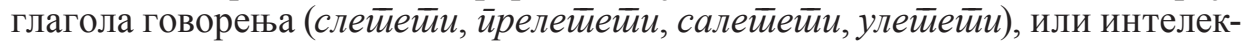

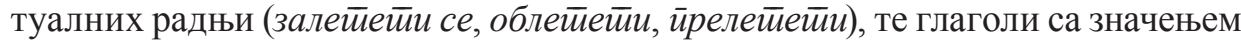

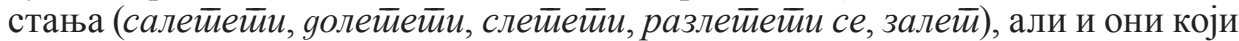

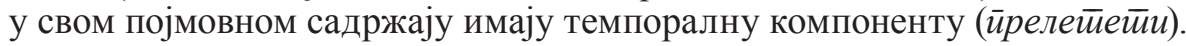


Остали деривати с мотивном речју летеиеии припадају доменима: простоРА

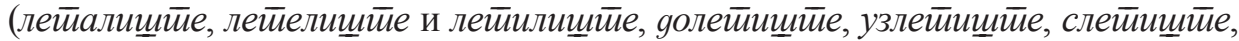

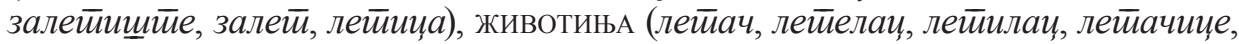

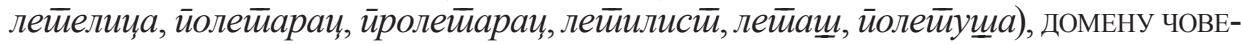

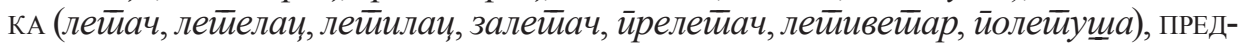

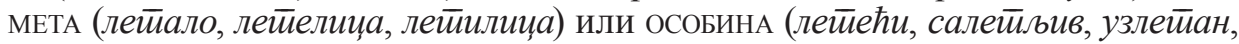

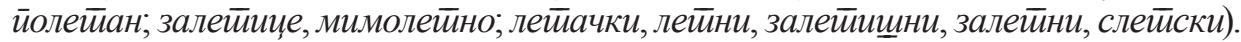

Чланови деривационог гнезда глагола лейетии припадају доменима који се логички развијају на основу обележја мотивног глагола, остајући тако У ДОМЕНУ РАДњЕ ОЗНачене мотиватором, али ширећи се и на дОМЕН ЖИВОтИњА којима је летење природно својство, те домЕн пРЕдмЕТА, односно апарата којима је летење основна функција, али и особа које управљају летелицама. Потоње је формализовано агентивним именицама, уз метафорично развијање атрибутивних именица персоналног типа, које је омогућено секундарним реализацијама претежно префиксираних глагола, као и радње и стања која не припадају домену кретања, већ су са обележјем глагола из домЕнА

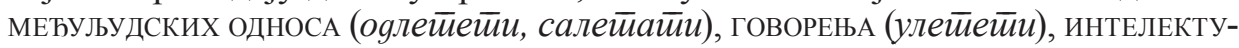

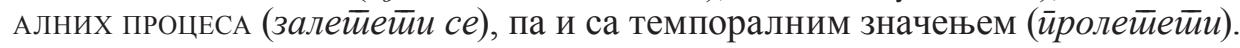

\section{ИЗВОР}

PMC: Речник срйскохрвайскойа књижевной језика, I-III. Нови Сад - Загреб: Матица српска - Матица хрватска, 1967-1969. Речник срӣскохрвайскойа књижевной језика, IV-VI. Нови Сад: Матица српска, 1969-1976.

\section{ЦИТИРАНА ЛИТЕРАТУРА}

АлАновић, Миливој. Типични структурно-семантички модели перифраза са глаголима просторно-мобилних односа. Зборник Мат̄ище срйске за филолоїију и линйвистиику LVI/2 (2013): 39-59.

ГортАн Премк, Даринка. Полисемија и орїанизација лексичкої систиема у срйскоме језику. Београд: Завод за уџбенике и наставна средства, 2004.

ДрАгићевић, Рајна. Лексиколойија срйской језика. Београд: Завод за уџбенике, 2007.

ЗыковА, Ирина Владимировна. Концейт̄осфера куль йуры и фразеолоїия. Теория и метиоgы линївокульйуролоїическоі̄о изучения. Москва: Ленанд, 2015.

ПоповА, Зинаида Даниловна, Иосиф Абрамович Стернин. Койнийивная линйвистиика. Москва: „Восток-Запад”, 2007.

РАЋеновић, Анка. Глаголски вид у српском и савременом грчком: између семантике и прагматике. Анали Филолощкой факулйейа 28/2 (2016): 285-302.

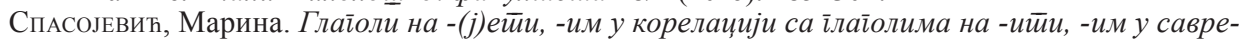

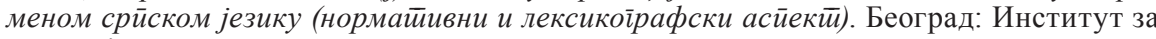
српски језик САНУ, 2013.

Стаменковић, Душан. Језик и крейање: койнийивносеманӣички ойлеgи. Ниш: Филозофски факултет, 2017.

Ћосит, Павле и сарадници. Речник синонима. Београд: Kornet, 2008.

ХАлАс, Ана. Глаголи кретања помоћу превозног средства: између лексиколошке теорије и лек-

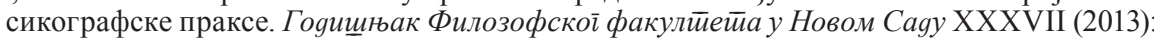
$285-300$. 
ШипкА, Милан. Летилица или лет(j)елица? (За чвршће критеријуме нормирања). Нам језик XXXIII/3-4 (2000): 244-253.

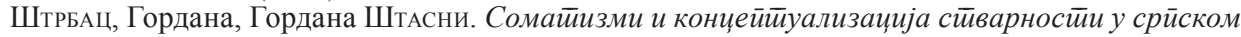
језику. Нови Сад: Филозофски факултет, 2017.

KovAČEvIĆ, Borko. Glagolske imenice u savremenoj lingvističkoj teoriji. Beograd: Filološki fakultet, 2016. LaLEvić, Miodrag. Sinonimi i srodne reči srpskohrvatskog jezika. Beograd: Nolit, 2004.

Miller, George A. English Verbs of Motion: A Case Study in Semantics and Lexical Memory. Arthur W. Melton, Edwin Martin (eds.). Coding Processes in Human Memory. New York: V. H. Winston and Sons - Helsted Press, 1972, 335-372.

MiLJKović, Vanja. Novi glagoli sa prefiksom $i z$ - u savremenom srpskom jeziku i teorija glagolske prefiksacije. Језици и кулишуре у времену и йростиору VII/2 (2018): 153-164.

NidA, Eugene. Componential Analysis of Meaning. The Hague - Paris: Mouton, 1975.

ORTHEN, Norbert. Zur Semantik deutscher Bewegungsverben. Köln: Univ., Diss.Inaugural-Dissertation, 1976.

VuJović, Dušanka. Glagoli ljudskog kretanja u savremenom srpskom jeziku-semantika i derivacija. Novi Sad: Filozofski fakultet, 2019. <http://digitalna.ff.uns.ac.rs/sadrzaj/2019/978-86-6065- 562-4>

Gordana Štasni

Milan Ajdžanović

\section{SEMANTIC-DERIVATIONAL POTENTIAL OF THE VERB LETETI 'FLY'}

\section{Su m m ary}

The verb leteti 'fly' is one of the fundamental lexical items in a significant category of motion verbs, a verb without a corresponding synonym, separated from other suchlike verbs on the basis of the space in which movement takes place. Using the principle of compositionality, the authors establish active components of meaning that give rise to the expansion of the verb's semantic structure. Depending on which component is active, there is a semantic transfer of metaphorical type both in terms of the semantic dispersion of the verb and its derivatives and derivations.

In accordance with the goals of the research, the authors made an effort to, based on meaning, ascertain the conceptual domains to which the derivatives of the motive verb leteti belong. The sheer volume of this derivational nest (121 units) clearly illustrates the semantic-derivational potential of the verb as well as the shift of the categorical boundary of motion towards those outside the domain of motion. The most extensive and simultaneously the most multilayered is the DOMAIN OF ACTION for the reason that together with derived words that denote movement in the air (let, letenje) or on the ground by a certain path (zalet) it also includes units from subdomains denoting stages in action development (ingressive (eg. poleteti), ablative (odleteti), adlative (poleteti), perlative (preleteti), meaning of diffuse movement (razleteti se), verbs denoting actions that have been brought to extremes (naleteti se), etc.). Special subdomains are derivatives that conceptualize action as a consequence of certain, mostly negatively evaluated interpersonal relationships (odleteti, naleteti) through metaphor, as well as items from the semantic category of verbs of speaking (uleteti), intellectual actions (preleteti) or stative verbs (saleteti), as well as those that have a temporal component in their conceptual content (proleteti). Other words derived from leteti belong to the following domains: SPACE (e.g., doletište, uzletište), ANIMAL (letač, letačice, poletuša), DOMAIN OF MAN (letač, preletač), OBJECT (letelica) and PROPERTy (leteći, saletljiv, uzletan, poletan).

Универзитет у Новом Саду

Филозофски факултет

Одсек за српски језик и лингвистику

Др Зорана Ђинђића 2, 21000 Нови Сад, Србија

gordanastasni@ff.uns.ac.rs

ajdzanovic@ff.uns.ac.rs
(Примљено: 27. августа 2021; прихваћено: 28. октобра 2021) 